\title{
Demand-oriented Supply Chain Strategies - A Review of the Literature
}

\author{
Chuda Basnet \\ University of Waikato \\ Hamilton, New Zealand \\ Email: chuda@waikato.ac.nz (Corresponding Author) \\ Stefan Seuring \\ University of Kassel \\ Kassel, Germany \\ Email: seuring@uni-kassel.de
}

\begin{abstract}
This paper presents a review of the research literature on supply chain strategies linked to product demand. Fisher (1997), in his seminal article, has argued that efficient supply chain (SC) strategies are appropriate for functional products and responsive strategies are needed for innovative products. The purpose of this article is to review articles which have been published after Fisher (1997), and which relate market demand for a product to the respective supply chain design, in an effort to synthesise these articles and suggest future research directions. A literature review is carried out using content analysis, following the qualitative research paradigm. Both deductive and inductive coding has been carried out, followed by a descriptive analysis and a synthesis of the literature. The contribution of the article is a critical review, a synthesis of the literature, and directions for future research.
\end{abstract}

Keywords: Supply chain strategy, Literature review, Content analysis, Efficient / responsive, Lean / agile / leagile.

\section{INTRODUCTION}

Supply chain management (SCM) emphasises holistic management of the network of organisations, often labelled supply chain (SC), which is involved in producing and delivering a product to the customer. SCM applies systems thinking to the provision of products recognising that multiple organisations are involved in this provision. Performance improvements can be achieved if these organisations work together. Understandably, much SCM research is focused on supply chain integration. Another stream of research is concerned with the strategic alignment of supply chains to the contingencies of products and markets. The central argument in this research stream is that the requirements in the provision of products change across products and markets. Accordingly supply chains need to be configured on the basis of the products they produce and the markets they serve. A significant amount of research has been carried out in this stream, but the underlying criteria have not been assessed and structured for providing a systemisation of related arguments.

Thus the aim of this paper is to provide a systematic and critical review of this research stream and to contribute some propositions and a framework that would synthesise current research. We begin with a background to the literature, which is followed by a discussion of the research methodology followed in this paper. The findings are presented in two parts: a descriptive analysis and a thematic analysis. Finally, we discuss our findings and end with some conclusive remarks.

\section{BACKGROUND}

The concept of strategic alignment can be traced back to the work of Skinner (1969 \& 1974), who pointed out that manufacturing tasks change as products/markets change. These tasks may require excellence in quality, delivery, or reliability, etc. According to Skinner, "a factory cannot perform well on every yardstick", however manufacturers adopted a single yardstick - productivity or efficiency. Thus manufacturing management could be out of alignment with the manufacturing task. Skinner advocated "focused factories", where the production facility was aligned with the manufacturing task engendered by its products/markets. When a manufacturer was operating with multiple products/markets, each with its own manufacturing tasks, Skinner suggested dividing up a facility into multiple separate production areas, the so-called "plant within a plant" (PWP), each addressing a particular manufacturing task. Skinner's work was influential in generating a significant amount of research in the area of manufacturing strategy. As the scope of production / operations management extended from an individual firm to the supply chain, the research on strategic alignment has also extended its scope to supply chain management. Fisher (1997) presented a 2 x 2 matrix (Figure 1, below) with products (functional or innovative) on the $\mathrm{x}$-axis and supply chains (efficient or responsive) on the y-axis. Functional products, sometimes labelled 
commodity products, have low product variety and their demand is predictable; whereas innovative products, typically technology products, have high product variety and low predictability of demand. Efficient supply chains are designed to lower costs and typically have high capacity utilisation; responsive supply chains are designed to service unpredictable demand, typically by having a capacity cushion or inventory buffers. Fisher asserted that functional products should be aligned with efficient supply chains and responsive supply chains are required for innovative products. The other two combinations in the matrix (functional product with responsive supply chain and innovative product with efficient supply chain) represent a misalignment and would result in diminished performance.

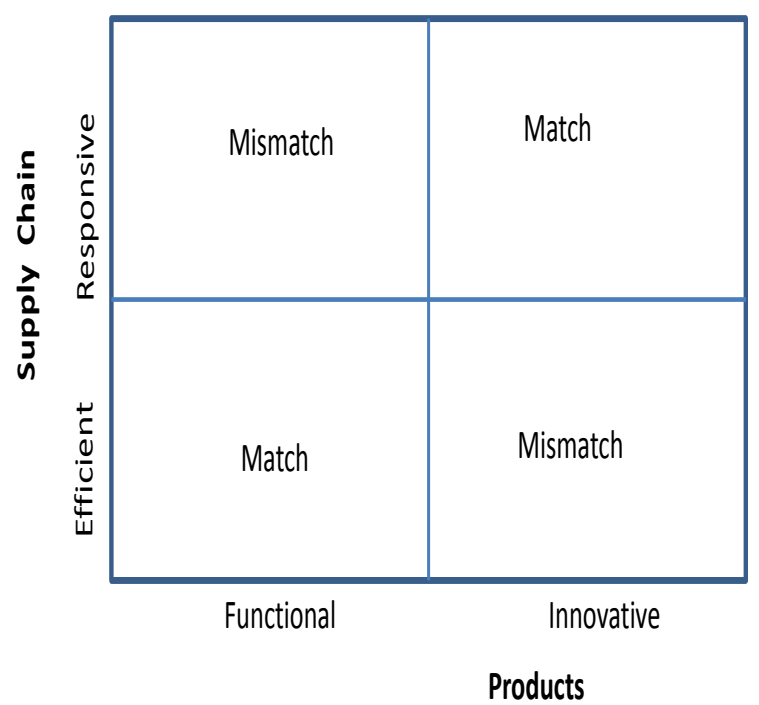

Figure 1 Fisher's (1997) model matching product types with supply chain types

Fisher's seminal article (Fisher, 1997) has been followed by a stream of research investigating the alignment between product/market requirements and supply chain strategies. The major thrust of this research stream is to investigate how supply chains are configured in response to product/market contingencies. Figure $\mathbf{2}$ outlines the over-riding theme of these articles. The external environment engenders certain contingencies; supply chain configurations are designed in response to these contingencies; and a cluster of configurations constitute a strategy to enhance the performance of the supply chain. Contingencies are product / market requirements or exogenous variables in the design of supply chains. Configurations are elements of the design, constituting long-term strategic decisions or dependent variables. A set of these long-term decisions would be a supply chain strategy. These themes - contingency, configuration, and strategy constitute the deductive (or a priori) themes conceptualised in this paper.

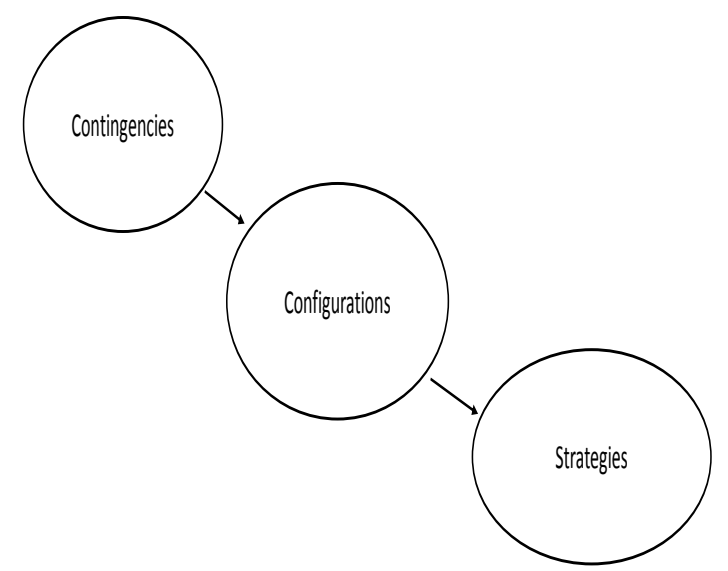

Figure 2 Deductive (or a priori) Themes

Even though significant amount of research has accumulated, a review of the research has not been undertaken yet and would therefore be timely. In the next section we present our research methodology. This is done first, as the logical flow of arguments is improved this way. As the aim of the paper is a literature review itself, there is no literature review section upfront.

\section{RESEARCH METHODOLOGY}

Literature reviews, essentially being analyses of written communication, quite often adopt the technique of content analysis (Kassarjian, 1977). Accordingly, various researchers, such as Seuring \& Gold (2012) have proposed the use of content analysis as an excellent tool to conduct rigorous, systematic, and reproducible literature reviews in SCM. Content analysis, as introduced by Berelson (1952), focusses on uncovering the "objective, systematic and quantitative description of the manifest content of communication". Krippendorff (2012) defines content analysis as being "a research technique for making replicable and valid inferences from texts (or other meaningful matter) to the contexts of their use" (p. 24).

The aim of content analysis is to derive hidden patterns within the data under review so as to derive new insights from the content under review. The process of content analysis, followed here, is often summarized into four steps (Mayring, 2010) and has been applied to literature reviews already (Seuring and Gold, 2012):

1. Material or data collection, where the steps taken in collecting the materials to be analysis is collected from different sources.

2. The descriptive analysis offers some first insights into the data on a descriptive level, so that the body of data to be analysed is characterised.

3. The next step is the category selection, where the single categories for the data analysis are outlined. Content analysis is based on categories or themes. Each individual article or its content 
is classified on the basis of these categories, and the occurrence of the categories are analysed. The categories may be ad-hoc (or deductive) or post-hoc (or inductive). Both deductive and inductive categories were used in this research.

4. The material evaluation links the data to the analytic categories, so that they are applied. This often combines quantitative arguments on how often certain issues are mentioned with more qualitative arguments being made on the reasoning of the researcher by working with the analysed material.

Validity and reliability issues also need to be addressed in content analysis. One of the governing conditions of content analysis is usually to reach intercoder reliability, which can be achieved by employing more than one coder. This, however, comes at the cost of being very time consuming. Hence this has only be done for parts of the material in this case (about 10\%), which was deemed sufficient to ensure a basic joint comprehension of constructs between the researchers involved. This also addresses aspects of construct validity, as most of the categories are taken from the body of literature analysed. The intensive discussion within the research team, combined with the presentation of findings in internal seminars, contributes to external validity as the argumentation for construct development can be justified beyond the scope of the small research team. There is still a degree of discretion in interpreting data and findings, but this holds for many empirical research methods and can only be addressed by crafting convincing arguments.

\subsection{Collection of Data}

Articles citing Fisher (1997) were identified from the following databases that indexed citations.

Web of knowledge (618 articles)

Google Scholar (1000 articles)

Further articles meeting our criteria were collected from the references cited in the reviewed articles adding a snowballing effect to the data collection.

A very large number of articles citing Fisher (1997) were found. The criteria for selection of articles for review were:

1. Peer-reviewed journal articles,

2. English language papers,

3. Published in the period 1997-2013. The year 1997 was chosen as a framing data due to the publication of Fisher's article in that year.

4. Focusing on the nexus between supply chain product-market contingencies and supply chain configurations. (The article was required to have the three themes identified in Figure 2).

Our search identified many articles focusing on supply chain strategies labelled collaborative, lean, agile, sustainable, responsive etc. The focus of many of these articles was on supply chain objectives, however if they did not specifically address the alignment between contingencies of products-markets and supply chain configurations, those articles were not included in the review. In this way, the final tally of articles included in this review stood at 55.

To validate the data search, a separate search was made on the following databases, looking for "supply chain strategy" or "supply chain strategies" in title, abstract, or keywords fields of articles.

\section{Proquest (233 articles), \\ Ebsco (446 articles), \\ Emerald Insight (103 articles), and \\ Science Direct (60 articles)}

This additional search yielded only 3 more articles to be included in the review, providing some assurance that the bulk of articles confirming to our search criteria have been included.

We admit that only following up on papers citing the Fisher (1997) paper is one of the major limitations for this research endeavour. A structured keyword search for various terms might have been a further option. Yet, we would argue that papers in the field (a) would cite the Fisher paper and (b) that this approach also allows limiting the total number of papers obtained to a level that is manageable for such an analysis. The repeatability as a major aspect of reliability of the study is ensured by the description of the research process. This is the core aspect covered here as other, i.e. statistical measures of reliability are not applicable. Internal validity of the research is ensured through the coding procedure (Seuring and Gold, 2014). While this is dependent on the judgements of the coder in the process, all papers have been treated in the same manner. Construct validity is ensured by linking our analysis into the extant literature. External validity was hard to address, as we have no other data supporting our analysis.

In the next section a descriptive analysis of the collected articles is presented.

\section{DESCRIPTIVE ANALYSIS}

\subsection{Year of Publication}

The number of reviewed articles is plotted against the year of publication below in Figure 3. It may be observed that it took three years after the publication of Fisher's (1997) article for the interest in this area to pick up. Highest number of articles were published in 2002. Lately the number of articles have started to settle to a lower rate, but there is still continued interest and relevance. This can also be seen by the fact that against data from Google Scholar, the paper received more than 200 citations in each subsequent year since 2006. 


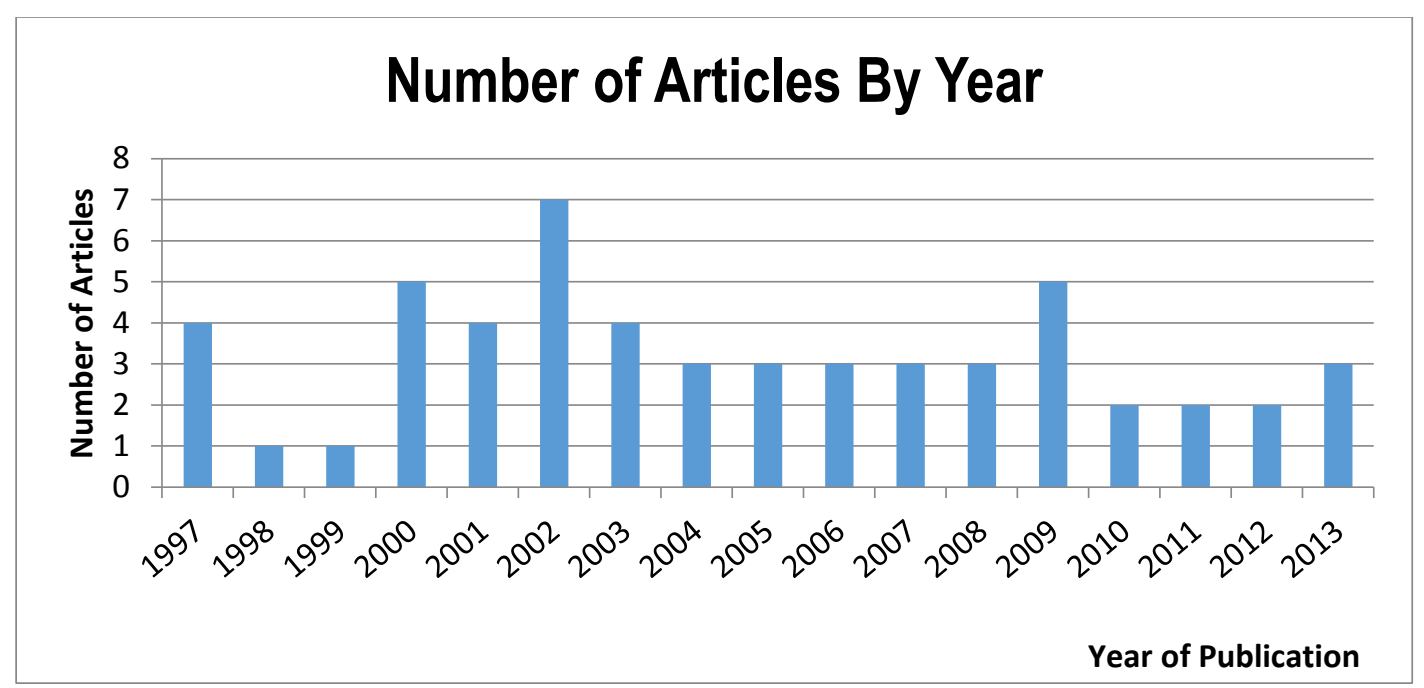

Figure 3 Number of Articles Published by Year

\subsection{Research Methodologies Used in the Reviewed Papers}

The research methodology followed in the reviewed articles is plotted in Figure 4. By far the greatest number of articles are theoretical in nature. Articles using the survey methodology are only a few in number. This indicates that this field has not yet matured to a field testing stage.

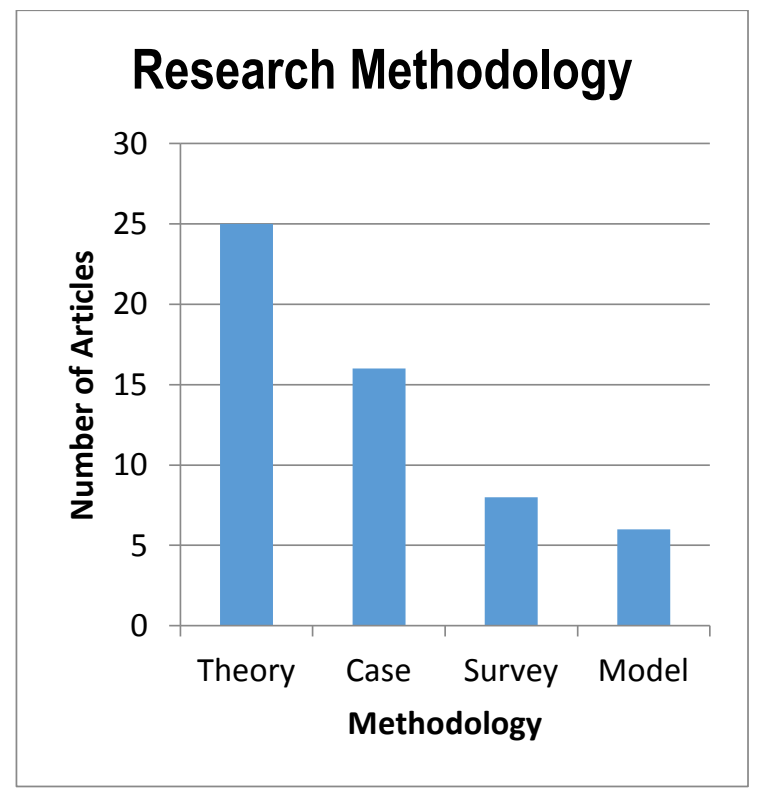

Figure 4 Research Methodology in the Reviewed Papers

The relative lack of theoretical development and testing is also shown in Table 1, which classified the articles into prescriptive and descriptive articles. There are far more articles focusing on prescribing appropriate SC strategies to the manager than articles carrying out field analysis that described and explained supply chains in the field.
Table 1 Number of Prescriptive and Descriptive Articles

\begin{tabular}{|l|l|}
\hline Prescriptive & 32 \\
\hline Descriptive & 23 \\
\hline
\end{tabular}

Thus a finding is that apparently it is time to move from theorising to field analysis in this area.

\section{THEMATIC ANALYSIS}

Since this review concerns the alignment between contingencies of products / markets and supply chain configurations, we had both deductive or ad-hoc categories consisting of contingencies, configurations, and strategies, as shown in Figure 2 earlier. Sub-issues within these themes were identified and coded inductively as the literature review progressed. These sub-themes are discussed next.

\subsection{Contingencies}

A list of the numerous contingency categories identified in the reviewed literature appears in Table 2. The frequency distribution of the contingencies is also given in the table.

The consensus in the current literature is that the most important contingency variable in SC strategy is demand variability / uncertainty. Product variety and customer lead time are other significant determinants of supply chain strategy.

The sheer number of contingency variables in the above table raises a question regarding the extent to which these variables are all necessary for the determination of supply chain strategies. Some of the contingencies are obviously dependent on each other. For example, small production volumes, short product life, large product variety, all add to the variability of product demand. Thus a finding of our research is the need for more work to identify a parsimonious set of contingency variables that would underpin all the variations in supply chain strategies. 
Table 2 Contingency Categories in the Reviewed Literature

\begin{tabular}{|c|c|c|c|}
\hline Contingency & Definition & References & $\begin{array}{c}\text { Count } \\
(\mathrm{N}=55)\end{array}$ \\
\hline Demand variability / uncertainty & $\begin{array}{l}\text { This contingency refers to the inability to } \\
\text { forecast product demand accurately, which } \\
\text { results in possible obsolescence and mark- } \\
\text { down of prices. }\end{array}$ & $\begin{array}{l}\text { Fisher, Hammond, Obermeyer, \& } \\
\text { Raman, 1997; Naylor, Naim, \& Berry, } \\
\text { 1999; Childerhouse, Aitken, \& Towill, } \\
\text { 2002; Olhager, 2003; Lo \& Power, } 2010\end{array}$ & 42 \\
\hline Product variety & $\begin{array}{l}\text { Products may be characterised as being } \\
\text { standard (less variety) or customised (high } \\
\text { variety). }\end{array}$ & $\begin{array}{l}\text { Fisher et al., 1997; Pagh \& Cooper, } \\
\text { 1998; van der Vorst, van Dijk, \& } \\
\text { Beulens, 2001; Waddington, } \\
\text { Childerhouse, \& Towill, 2002; } \\
\text { Vonderembse, Uppal, Huang, \& } \\
\text { Dismukes, } 2006\end{array}$ & 36 \\
\hline Customer lead time & $\begin{array}{l}\text { Customer lead time refers to the importance } \\
\text { placed by the customer on quick delivery. }\end{array}$ & $\begin{array}{l}\text { Aitken, Christopher, \& Towill, 2002; } \\
\text { Olhager, 2003; Christopher \& Gattorna, } \\
\text { 2005; Collin, Eloranta, \& Holmström, } \\
\text { 2009; Borgström \& Hertz, } 2011 \\
\end{array}$ & 26 \\
\hline Length of product life cycle & $\begin{array}{l}\text { A short product life accentuates the risk of } \\
\text { obsolescence. }\end{array}$ & $\begin{array}{l}\text { Naylor et al., 1999; Lamming, Johnsen, } \\
\text { Zheng, \& Harland, 2000; Childerhouse } \\
\text { et al., 2002;Waddington et al., 2002; } \\
\text { Wagner, Grosse-Ruyken, \& Erhun, } \\
2012\end{array}$ & 12 \\
\hline Volume of production & $\begin{array}{l}\text { Large production runs can take advantage of } \\
\text { economy of scale, whereas small production } \\
\text { runs require rapid reconfiguration. }\end{array}$ & $\begin{array}{l}\text { Pagh \& Cooper, 1998; Christopher, } \\
\text { 2000; Childerhouse et al., 2002; } \\
\text { Olhager, 2003; Payne \& Peters, } 2004\end{array}$ & 11 \\
\hline Supply uncertainty & $\begin{array}{l}\text { Raw material supplies to the focal firm may be } \\
\text { disrupted by various causes, such as natural } \\
\text { disaster, yield losses, quality issues, etc. }\end{array}$ & $\begin{array}{l}\text { Lee, 2002; Yang, Burns, \& Backhouse, } \\
\text { 2004; Towill \& Christopher, 2007; } \\
\text { Caniato, Caridi, Castelli, \& Golini, 2009; } \\
\text { Sun, Hsu, \& Hwang, } 2009\end{array}$ & 8 \\
\hline Customer service & $\begin{array}{l}\text { Customer service refers to the ability to fill rate, } \\
\text { the proportion of customer demand that is filled } \\
\text { from stock. }\end{array}$ & $\begin{array}{l}\text { Fisher, 1997; Pagh \& Cooper, 1998; } \\
\text { Lovell, Saw, \& Stimson, 2005; Harris, } \\
\text { Componation, \& Farrington, 2010; Lo \& } \\
\text { Power, } 2010\end{array}$ & 7 \\
\hline Contribution margin & $\begin{array}{l}\text { When the mark-up on a product is low, there is } \\
\text { more emphasis on cost-efficiency of } \\
\text { production. }\end{array}$ & $\begin{array}{l}\text { Fisher, 1997; Randall, Morgan, \& } \\
\text { Morton, 2003; Selldin \& Olhager, 2007; } \\
\text { Harris et al., 2010; Lo \& Power, } 2010\end{array}$ & 6 \\
\hline Stage of product life cycle & $\begin{array}{l}\text { The demand for a product changes with the } \\
\text { stage of its product life cycle, the demand at } \\
\text { the introduction stage is small and uncertain, } \\
\text { but at the mature stage the demand is high and } \\
\text { stable. }\end{array}$ & $\begin{array}{l}\text { Pagh \& Cooper, 1998; Childerhouse et } \\
\text { al., 2002; Cigolini, Cozzi, \& Perona, } \\
\text { 2004; Vonderembse et al., } 2006\end{array}$ & 4 \\
\hline Rate of market growth & $\begin{array}{l}\text { Rate of market growth changes with the stage } \\
\text { of the product life cycle. }\end{array}$ & $\begin{array}{l}\text { Fisher, 1997; Randall et al., 2003; } \\
\text { Harris et al., 2010; Lo \& Power, } 2010\end{array}$ & 4 \\
\hline Complexity of product structure & $\begin{array}{l}\text { The bill of material of a product may be simple } \\
\text { or complex, with multiple components and sub- } \\
\text { assemblies. }\end{array}$ & $\begin{array}{l}\text { Lamming et al., 2000; Cigolini et al., } \\
\text { 2004; Caniato et al., } 2009\end{array}$ & 3 \\
\hline Markdowns & $\begin{array}{l}\text { Markdowns occur when prices are reduced } \\
\text { because of stocking higher than demand. }\end{array}$ & $\begin{array}{l}\text { Fisher, 1997; Harris et al., 2010; Lo \& } \\
\text { Power, } 2010\end{array}$ & 3 \\
\hline Value density & The ratio of product value to product weight. & $\begin{array}{l}\text { Pagh \& Cooper, 1998; } \\
\text { Lovell et al., } 2005\end{array}$ & 2 \\
\hline Uniqueness & $\begin{array}{l}\text { The degree of difficulty in replicating a product } \\
\text { by competitors. }\end{array}$ & $\begin{array}{l}\text { Lamming et al., 2000; Caniato et al., } \\
2009\end{array}$ & 2 \\
\hline
\end{tabular}

(There are some other contingencies (mentioned only once in the literature), which have not been included in the above list.)

\subsection{Configurations}

Configurations are levers that managers are able to pull, based on the contingencies posed by the external environment. Research has identified many designs for supply chain configurations that will align with the contingencies mentioned above. The subthemes under the a priori theme of configurations were identified as the literature review progressed and are listed below in Table 3. A frequency distribution of the configurations is also given. 
Table 3 Configuration Categories in the Reviewed Literature

\begin{tabular}{|c|c|c|c|}
\hline Configuration & Definition & References & Incidence $(\mathrm{N}=55)$ \\
\hline $\begin{array}{l}\text { Positioning of decoupling } \\
\text { point and postponement }\end{array}$ & $\begin{array}{l}\text { Decoupling point (or order penetration point) refers } \\
\text { to the point in the supply chain where an inventory } \\
\text { is maintained and where individual customer orders } \\
\text { are executed and moved downstream. As the } \\
\text { decoupling point is moved upstream, the production } \\
\text { / distribution operations are progressively } \\
\text { "postponed". }\end{array}$ & $\begin{array}{l}\text { Feitzinger \& Lee, 1997; } \\
\text { Pagh \& Cooper, 1998; } \\
\text { Olhager, 2003; } \\
\text { Lo \& Power, 2010; Borgström } \\
\text { \& Hertz, } 2011\end{array}$ & 30 \\
\hline Waste elimination & $\begin{array}{l}\text { The literature on lean management has identified } \\
\text { seven wastes (or mudas) to eliminate: } \\
\text { overproduction, waiting time, transportation, } \\
\text { inventory, processing waste, motion, and product } \\
\text { defects. Wastes, by definition, use up resources } \\
\text { without improving production or services, thus } \\
\text { waste reduction is consistent with efficiency } \\
\text { improvement. }\end{array}$ & $\begin{array}{l}\text { Naylor et al., 1999; } \\
\text { Christopher \& Towill, 2001; } \\
\text { Towill \& Christopher, 2002; } \\
\text { Randall et al., 2003; } \\
\text { Qi, Boyer, \& Zhao, } 2009\end{array}$ & 13 \\
\hline Manufacturing capacity & $\begin{array}{l}\text { Manufacturing capacity obviously plays a part in the } \\
\text { throughput rate and the lead times achieved by a } \\
\text { supply chain. Higher capacity will also permit a } \\
\text { degree of flexibility in production variety or volume } \\
\text { without penalising customer service or customer } \\
\text { lead time. }\end{array}$ & $\begin{array}{l}\text { Fisher et al., 1997; } \\
\text { Christopher \& Towill, 2000; } \\
\text { Randall et al., 2003; Qi et al., } \\
\text { 2009; Lo \& Power, } 2010\end{array}$ & 10 \\
\hline Lead time reduction & $\begin{array}{l}\text { A reduction in lead time will obviously improve } \\
\text { customer service by improving response times. It } \\
\text { will also improve forecasting by allowing the use of } \\
\text { forecasts closer to the event of demand. Lead time } \\
\text { reduction may be achieved by various means such } \\
\text { as process improvement, automation of order } \\
\text { processing, use of inter organisational information } \\
\text { systems, etc. }\end{array}$ & $\begin{array}{l}\text { Fisher et al., 1997; } \\
\text { Christopher \& Towill, 2001; } \\
\text { Waddington et al., 2002; } \\
\text { Selldin \& Olhager, 2007; } \\
\text { Harris et al., } 2010\end{array}$ & 10 \\
\hline Information sharing & $\begin{array}{l}\text { Sharing of demand information, such as point-of- } \\
\text { sales (POS) data, permits the whole supply chain to } \\
\text { work together. Information sharing allows inventory } \\
\text { storage at optimal locations in optimal quantities. } \\
\text { Various supply chain initiatives designed to match } \\
\text { supply and demand, such as efficient customer } \\
\text { response, quick response, and continuous } \\
\text { replenishment are based on information sharing. }\end{array}$ & $\begin{array}{l}\text { Fisher, 1997; Christopher, } \\
\text { 2000; } \\
\text { Randall et al., 2003; Caniato } \\
\text { et al., 2009; } \\
\text { Lo \& Power, } 2010\end{array}$ & 9 \\
\hline Supply chain integration & $\begin{array}{l}\text { An integrated supply chain consists of flow of } \\
\text { information upstream and streamlined flow of } \\
\text { materials downstream of the supply chain. Demand } \\
\text { information is communicated upstream so that all } \\
\text { parties can plan their operations without the } \\
\text { bullwhip effect. }\end{array}$ & $\begin{array}{l}\text { Naylor et al., 1999; } \\
\text { Christopher \& Towill, 2000; } \\
\text { Aitken et al., 2002; } \\
\text { Lee, 2002; } \\
\text { Waddington et al., } 2002\end{array}$ & 8 \\
\hline Modularisation & $\begin{array}{l}\text { A modular design permits standardisation of } \\
\text { components (modules), even when the finished } \\
\text { product is customised from these modules. Where } \\
\text { customisation or a high variety of products is } \\
\text { demanded by customers, modularisation offers } \\
\text { inventory savings through the concept of inventory } \\
\text { pooling. }\end{array}$ & $\begin{array}{l}\text { Feitzinger \& Lee, 1997; } \\
\text { Fisher, 1997; } \\
\text { Christopher \& Towill, 2001; } \\
\text { Yang et al., 2004; Lo \& Power, } \\
2010\end{array}$ & 7 \\
\hline $\begin{array}{l}\text { Continuous } \\
\text { replenishment }\end{array}$ & $\begin{array}{l}\text { This is a programme where the retailer } \\
\text { communicates to the manufacturer the daily } \\
\text { demand and levels of inventory, and the supplier, in } \\
\text { turn, maintains inventory levels at the retailer's } \\
\text { facility within prescribed limits by frequent shipment. }\end{array}$ & $\begin{array}{l}\text { Fisher, 1997; Christopher \& } \\
\text { Towill, 2001; Aitken et al., } \\
\text { 2002; Harris et al., 2010; Lo \& } \\
\text { Power, } 2010\end{array}$ & 7 \\
\hline
\end{tabular}


Table 3 Configuration Categories in the Reviewed Literature (continued)

\begin{tabular}{|c|c|c|c|}
\hline Inventory buffer stock & $\begin{array}{l}\text { Maintaining an inventory of finished goods } \\
\text { decouples demand from production, thus allowing } \\
\text { production to be scheduled with higher efficiency. } \\
\text { High inventory levels also allow for quicker } \\
\text { response and higher customer service, however this } \\
\text { also incurs the danger of obsolescence for products } \\
\text { with short product life cycles. }\end{array}$ & $\begin{array}{l}\text { Fisher, 1997; Selldin \& } \\
\text { Olhager, 2007; Harris et al., } \\
\text { 2010; Lo \& Power, 2010; } \\
\text { Wagner et al., } 2012\end{array}$ & 7 \\
\hline Level scheduling & $\begin{array}{l}\text { Level scheduling is a concept derived from the } \\
\text { Toyota Production System, where the planned } \\
\text { annual production was split into a number of } \\
\text { production lots and scheduled uniformly across the } \\
\text { year. In this way variability of the dependent internal } \\
\text { and upstream demand was reduced. }\end{array}$ & $\begin{array}{l}\text { Naylor et al., 1999; Mason- } \\
\text { Jones, Naylor, \& Towill, } \\
\text { 2000b; Christopher \& Towill, } \\
\text { 2000; Aitken et al., 2002; } \\
\text { Waddington et al., } 2002\end{array}$ & 6 \\
\hline $\begin{array}{l}\text { Selection of appropriate } \\
\text { suppliers }\end{array}$ & $\begin{array}{l}\text { Suppliers are increasingly called upon to align } \\
\text { themselves with the products / markets. Thus where } \\
\text { the market calls for lowering costs, suppliers may } \\
\text { be selected on the basis of costs; where the market } \\
\text { calls for speed of delivery, suppliers may be } \\
\text { selected on the basis of extra capacity. }\end{array}$ & $\begin{array}{l}\text { Fisher, 1997; Childerhouse et } \\
\text { al., 2002; Qi et al., 2009; } \\
\text { Harris et al., 2010; Lo \& } \\
\text { Power, } 2010\end{array}$ & 6 \\
\hline Rapid reconfiguration & $\begin{array}{l}\text { When production runs change, firms often spend } \\
\text { considerable resources to set-up for the new } \\
\text { products. This is an incentive for large lot sizes and } \\
\text { inventory holdings. The Toyota Production System } \\
\text { pioneered the improvement of set-up processes to } \\
\text { permit quick set-ups. Quick set-ups are an } \\
\text { advantage for any company since it improves } \\
\text { capacity directly. }\end{array}$ & $\begin{array}{l}\text { Naylor et al., 1999; } \\
\text { Christopher, 2000; } \\
\text { Christopher \& Towill, 2001; } \\
\text { Aitken et al., 2002; } \\
\text { Waddington et al., } 2002\end{array}$ & 5 \\
\hline Improved forecasting & $\begin{array}{l}\text { Some authors have laid emphasis on improved } \\
\text { forecasting to better match supply with demand. } \\
\text { This may involve use of early signals from the } \\
\text { market or use of expert opinions or advanced } \\
\text { forecasting models. }\end{array}$ & $\begin{array}{l}\text { Fisher et al., 1997; Fisher, } \\
\text { 1997; Selldin \& Olhager, } \\
\text { 2007; Harris et al., 2010; Lo \& } \\
\text { Power, } 2010\end{array}$ & 5 \\
\hline $\begin{array}{l}\text { Centralisation / } \\
\text { decentralisation of } \\
\text { inventory } \\
\end{array}$ & $\begin{array}{l}\text { Centralisation of inventory refers to the holding of } \\
\text { inventory at a central location for distribution. }\end{array}$ & $\begin{array}{l}\text { Randall \& Ulrich, 2001; Lee, } \\
\text { 2002; Payne \& Peters, 2004; } \\
\text { Lovell et al., } 2005\end{array}$ & 5 \\
\hline Kanban & $\begin{array}{l}\text { Kanban refers to the production control system, } \\
\text { derived from the Toyota Production System, where } \\
\text { production at each workstation is controlled by } \\
\text { replenishment signals from downstream } \\
\text { workstations. }\end{array}$ & $\begin{array}{l}\text { Childerhouse et al., 2002; } \\
\text { Aitken, Childerhouse, \& Towill, } \\
\text { 2003; Cigolini et al., 2004; } \\
\text { Aitken, Childerhouse, } \\
\text { Christopher, \& Towill, } 2005\end{array}$ & 4 \\
\hline Top up pipeline & $\begin{array}{l}\text { Some authors have suggested dual supply lines: a } \\
\text { slow but lower-cost bulk supplier, which is topped } \\
\text { up by another supplier for urgent needs. }\end{array}$ & $\begin{array}{l}\text { Christopher \& Towill, 2002; } \\
\text { Towill \& Christopher, 2002; } \\
\text { Randall et al., } 2003\end{array}$ & 3 \\
\hline Alternative suppliers & $\begin{array}{l}\text { Alternative suppliers have been suggested to } \\
\text { overcome disruptions in the supply chain. }\end{array}$ & $\begin{array}{l}\text { Lee, 2002; Caniato et al., } \\
2009\end{array}$ & 3 \\
\hline Complex supply network & $\begin{array}{l}\text { Refers to the size and complexity of the supply } \\
\text { network of a focal firm. }\end{array}$ & $\begin{array}{l}\text { Lamming et al., 2000; } \\
\text { Caniato et al., } 2009\end{array}$ & 2 \\
\hline
\end{tabular}

The positioning of decoupling point, including the concept of postponement, is the most discussed type of configuration in the literature. This may involve concepts such as the design-to-order (DTO), make-to-order (MTO), assemble-to-order (ATO), or make-to-stock (MTS). Postponement may also involve the positioning of the decoupling point at the distribution stage of the supply chain. Manufacturing capacity buffers as well as lead time compression are other common responses to demand uncertainties and product variety.

\subsection{Strategies}

The third deductive theme identified in the reviewed research is "strategy". The prescriptive stream of the research has endeavoured to align clusters of product demand contingencies to clusters of supply chain configurations, which in essence constitute the strategies. In this section, we provide a brief review of the proposed strategies.

\subsubsection{Strategies for Functional / Innovative Products}

Fisher (1997) identified product clusters named "functional" and "innovative" and prescribed strategies labelled "physically efficient" and "marketresponsive" respectively (see Figure 1, p.74). Functional products were commodity products that were posited to have comparatively stable demand, low variety of products, small duration of product life 
cycle, and large customer lead times. A manufacturer offering innovative products keeps introducing new models comparatively frequently. Thus these models have a short product life and the demand is uncertain. The configuration of supply chain is mainly determined by the predictability of the demand and the duration of product life cycle. Where the demand is predictable, and the product has longer life cycle (functional products), the sole goal of the design is efficiency, which can be achieved by high capacity utilisation and reduced inventory levels. Fisher (1997) also prescribed "continuous replenishment" for functional products - this is a programme where the retailer communicates to the manufacturer daily demand and levels of inventory, and supplier, in turn, maintains inventory levels at the retailers within prescribed limits by frequent shipment. This cluster of configurations was labelled "efficient" strategy.

When the demand is unpredictable and/or the product life is short, some of the efficiency may have to be sacrificed by having excess buffer capacity and excess buffer stock, and by using modular design and by postponing the final assembly. Fisher (1997) also suggested using better forecasting techniques, and reducing customer lead times for these contingencies. This set of configurations was labelled "responsive" strategy.

Fisher (1997) posited the predictability of demand as the determinant for supply chain strategy; Lee (2002) contributed supply uncertainty as another determinant for strategy selection. In response to supply uncertainty, Lee (2002) suggested inventory pooling, multiple supply sources, and the use of the Internet for information sharing and for locating alternative suppliers.

\subsubsection{Lean / Agile Strategies}

A group of authors (the lean-agile school, as named in (Godsell, Diefenbach, Clemmow, Towill, \& Martin, 2011)) have made a continuing and significant collaborative contribution to the research on the nexus between products / markets and supply chain configurations through their investigation of strategies that have been labelled "lean" or "agile". These contributions are discussed below. See also (Godsell et al., 2011).

Demand variability, product variety, and production volumes are the contingencies governing the choice of strategies in this stream of research. Duration of life cycle and desired customer lead time have also been added to the mix of determinant contingencies (Childerhouse et al., 2002; Aitken et al., 2005), but the influence of these two contingencies does not appear to be significant, based on the evidence presented in the articles.

Based on the above contingencies, a lean or an agile strategy is prescribed. Low demand variability, high product variety, and high production volumes would indicate a lean strategy. Otherwise an agile strategy would be prescribed. The following table sums up the configurations in lean and agile strategies as defined by the authors in this school.

Table 4 Lean and Agile Strategies (source: (Waddington et al., 2002))

\begin{tabular}{|l|l|l|}
\hline Configuration & Lean & Agile \\
\hline Supply chain integration & Essential & Essential \\
\hline Lead time compression & Essential & Essential \\
\hline Waste elimination & Essential & Desirable \\
\hline Rapid reconfiguration & Desirable & Essential \\
\hline Postponement & Arbitrary & Essential \\
\hline Smooth demand/Level scheduling & Essential & Arbitrary \\
\hline
\end{tabular}

It is obvious from the above that agile strategy subsumes lean strategy. The elements associated with the lean paradigm (Shah \& Ward, 2007) are retained within the agile strategy; in addition, configurations of supply chain integration and information sharing are included.

The authors in this school have also suggested ways of combining lean and agile strategies. Naylor et al. (1999) suggested that the decoupling point should be moved upstream as the variety of products increases. The decoupling point would buffer any demand variation and stabilise the demand upstream of the decoupling point, thus enabling the lean strategy to be applied to the section upstream from the decoupling point. Supply chain operations downstream of the decoupling point would follow the agile strategy to cope with the variation of demand. They labelled this mixed strategy as "leagility". Christopher \& Towill (2001) have contributed three paths to mixing agile and lean strategies:

1) Using the $80-20$ rule, identify the $20 \%$ high volume products and use lean strategy, others can be manufactured using the agile strategy

2) Implementing postponement and using lean before decoupling point, and agile after the decoupling point (leagile strategy),

3) Dividing the total demand into base demand (using lean strategy) and surge demand (using agile strategy) (Christopher \& Towill, 2002; Stratton \& Warburton, 2003; Towill \& Christopher, 2002). This is the so-called "topup" strategy.

Based on five contingencies, labelled DWV3 (duration of life cycle, customer lead time, production volumes, product variety, and demand variability), Childerhouse et al. (2002) identified four clusters of products, each with its own pipeline, for a particular case company. Conceptually the concept of pipeline is akin to Skinner's idea of plant within a plant (PWP), each with its own focus (see also (Aitken et al., 2002)). Performance results indicated remarkable improvement in both efficiency and customer service when the four clusters were implemented. It is to be noted that not all of the five contingencies were found to be discriminating in the selection of pipelines. 


\subsubsection{Summary of Lean-agile Strategies}

Fisher (1997) divided products into functional and innovative, and suggested physically efficient and responsive strategies as respectively appropriate. The authors in the lean-agile school have mentioned commodities and fashion goods for product differentiation and prescribed the lean and agile strategies respectively. The arguments are similar to that of Fisher (1997). By all accounts, lean strategy in the lean-agile stream is similar to Fisher's physically efficient strategy, since both are cost-oriented. Similarly agile strategy is akin to responsive strategy, which focuses on customer service (fill rate). However, there has been no attempt in the literature at reconciling Fisher's efficient / responsive strategies with the lean / agile strategies of the lean-agile school.

\subsubsection{Life-cycle based strategies}

Cigolini et al. (2004) added another strategy in the continuum between Fisher's efficient and responsive strategies. This intermediate strategy was labelled "lean". They argued that at the introduction and decline stage of the life cycle, products have Fisher's innovative characteristics, and should have a "quick" (or responsive) configuration. At the maturation stage, simple products need efficient strategy, as suggested by Fisher (1997), however complex products require "lean" strategy because of the coordination needed for complex products (Figure 5). The in-between growth stage of life cycle would require the intermediate "lean" strategy.

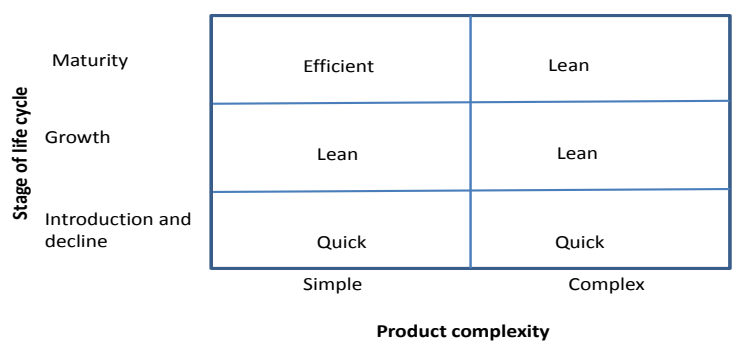

Figure 5 Cigolini’s Model (Authors' Interpretation)

In a similar vein, Aitken et al. (2003 \& 2005) assigned introduction stage of lifecycle to agile strategy, other stages to lean strategy. Vonderembse et al. (2006) assigned supply chain configurations to life cycle stages as well. Products could be standard, or innovative, or hybrid. Hybrid products would have a mix of standard and innovative components. Supply chains could be lean, agile, or hybrid (similar to leagile). Standard, innovative, and hybrid products are assigned to lean, agile, and hybrid supply chains. However, mature innovative products were assigned to hybrid strategy

In summary, product demand is most unpredictable during the introduction stage of a product life cycle. Authors are prescribing a responsive strategy during this time; at the maturity stage the demand is predictable and authors prescribe an efficient strategy. Thus we would argue that the variable "stages of product life cycle" does not add any more information regarding the demand, which is not captured by the variables of demand variability, production volumes, and product variety. Thus it should be possible to recast the above models in terms of these latter variables. The strategies proposed in this set of papers is in the continuum of efficient lean - responsive strategies, discussed earlier.

\subsubsection{Postponement Strategies}

A majority of authors have suggested using postponement in response to demand variation, product variety, and short product life cycles. As the decoupling point is moved further upstream production operations are postponed more, as depicted in Figure 6.

Feitzinger and Lee (1997) presented a case to illustrate the use of modularisation and postponement, when faced with the contingencies of product variety and customer lead time. The issue of variety was dealt with by modularisation and the issue of lead time was addressed by postponing final differentiation as late as possible. The modules were manufactured using mass manufacture, thus reducing cost. However, a small customer lead time was achieved by positioning the decoupling point at the distribution stage of the supply chain. This mixed strategy is a precursor to the leagile strategy (Naylor et al., 1999).

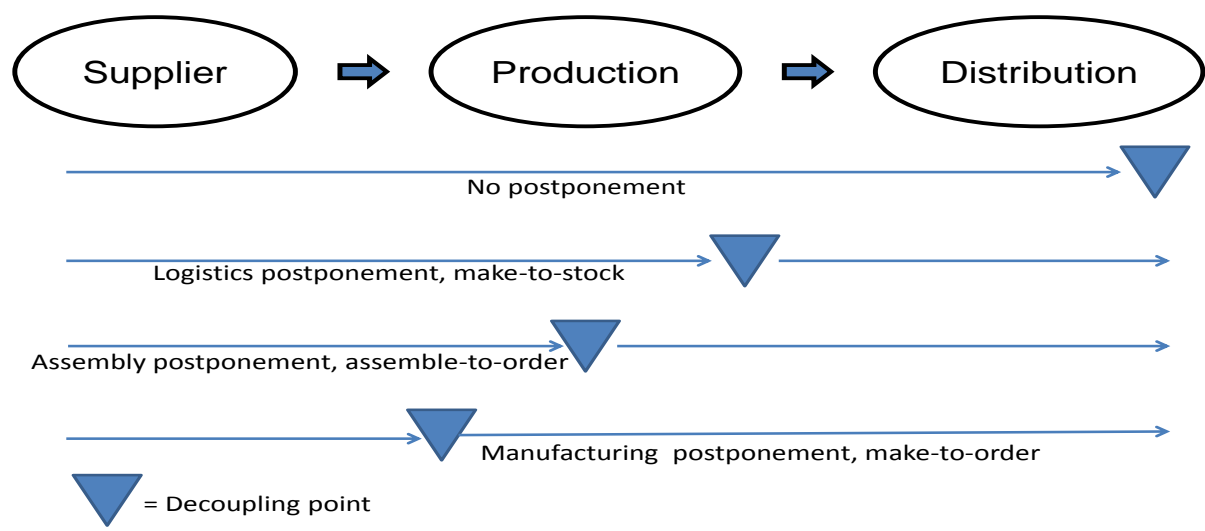

Figure 6 Positioning of decoupling point or postponement (based on Olhager, 2003) 
Pagh and Cooper (1998) have identified a continuum of four postponement strategies (and the corresponding positions of decoupling points). As mentioned above, assembling to order is a full postponement strategy; whereas maintaining inventory of finished product at the distribution stage is a full speculation (least postponement) strategy. If modules are inventoried at distribution stage and assembled to order there, logistics is speculative, but manufacturing is postponed. This was the case presented by Feitzinger and Lee (1997). Lastly, if finished product is inventoried at a central facility and distributed directly, manufacturing is speculative and logistics is postponed (Figure 7). Feitzinger and Lee (1997) aligned these strategies with a long list of market contingencies including duration and stage of product life cycle, demand uncertainty, customer lead time, customer service, product variety, volume of production, value profile, and value density. As demand variability increases, the choice moves from full speculation to full postponement. Similarly, a larger variety of products will have the same effect. Increase in value density will cause full speculation to be preferred.

\begin{tabular}{|c|c|c|c|}
\hline & \multicolumn{2}{|c|}{ Logistics } \\
\hline & & $\begin{array}{l}\text { Speculation } \\
\text { (Decentralised } \\
\text { inventories) }\end{array}$ & $\begin{array}{l}\text { Postponement } \\
\text { (Centralised } \\
\text { inventories and } \\
\text { direct } \\
\text { distribution) }\end{array}$ \\
\hline \multirow[t]{2}{*}{ Manufacturing } & $\begin{array}{l}\text { Speculation } \\
\text { (Make to } \\
\text { inventory) }\end{array}$ & $\begin{array}{l}\text { Full } \\
\text { speculation }\end{array}$ & $\begin{array}{l}\text { Logistics } \\
\text { postponement }\end{array}$ \\
\hline & $\begin{array}{l}\text { Postponement } \\
\text { (Make to order }\end{array}$ & $\begin{array}{l}\text { Manufacturing } \\
\text { postponement }\end{array}$ & $\begin{array}{l}\text { Full } \\
\text { postponement }\end{array}$ \\
\hline
\end{tabular}

Figure 7 Pagh and Cooper's (1998) taxonomy of postponement strategies
Olhager (2003) suggested positioning the decoupling point by comparing manufacturing lead time and the customer's desired lead time. If the manufacturing lead time is less, then the decoupling point could be moved upstream, otherwise it should be positioned downstream. Another factor is the predictability of demand: when the demand is predictable, full speculation may be desirable; otherwise moving decoupling point upstream is prescribed.

Postponement was proposed also as a part of responsive, agile, and leagile strategies discussed earlier. Postponement remains as the most popular configuration in response to demand uncertainty, product variety, and short product life cycles. However, postponement will increase customer response time and is not a suitable strategy where quick response is critical.

\subsubsection{Summary of strategies}

The strategy theme as found in the reviewed literature is summed up in Table 5. Although slight differences in emphasis can be observed, there is a significant commonality in the prescribed strategies. It is accepted that efficiency is a common goal in supply chain management. This may be achieved through such steps as waste elimination, kanban control, and level scheduling. Even though many contingencies have been discussed in the literature, the most significant determinants found in the reviewed literature are: demand variability / uncertainty, product variety, and customer lead time. When there is a presence of demand variability and product variety, the consensus in the literature is that postponement, increased manufacturing capacity, and rapid reconfiguration are required. Customer lead time is however a negative factor for postponement.

Table 5 Strategies and Their Determinants in the Literature

\begin{tabular}{|c|c|c|c|}
\hline $\begin{array}{l}\text { Strategy } \\
\text { theme }\end{array}$ & Determinants & Strategy prescriptions & Authors \\
\hline $\begin{array}{l}\text { Strategies for } \\
\text { functional / } \\
\text { innovative } \\
\text { products }\end{array}$ & $\begin{array}{l}\text { Duration of product life } \\
\text { cycle, demand } \\
\text { predictability, product } \\
\text { variety, supply maturity }\end{array}$ & Efficient / responsive strategies & Fisher, 1997; Lee, 2002 \\
\hline $\begin{array}{l}\text { Lean / agile } \\
\text { strategies }\end{array}$ & $\begin{array}{l}\text { DWV3 (duration of life } \\
\text { cycle, customer lead } \\
\text { time, production } \\
\text { volumes, product } \\
\text { variety, and demand } \\
\text { variability) }\end{array}$ & Lean / agile / leagile strategies & $\begin{array}{l}\text { Naylor et al., 1999; Mason-Jones, Naylor, \& Towill, 2000a; } \\
\text { Christopher \& Towill, 2001; Aitken et al., 2002; Christopher \& } \\
\text { Towill, 2002; Childerhouse et al., 2002; Waddington et al., 2002; } \\
\text { Towill \& Christopher, 2002; Stratton \& Warburton, 2003; Aitken et } \\
\text { al., 2003; Aitken et al., 2005; Christopher et al., 2006; Towill \& } \\
\text { Christopher, 2007; Godsell et al., } 2011\end{array}$ \\
\hline $\begin{array}{l}\text { Life cycle } \\
\text { based } \\
\text { strategies }\end{array}$ & $\begin{array}{l}\text { Stage of product life } \\
\text { cycle, product } \\
\text { complexity, product } \\
\text { innovativeness }\end{array}$ & $\begin{array}{l}\text { Efficient / responsive / lean / hybrid } \\
\text { strategies }\end{array}$ & $\begin{array}{l}\text { Aitken et al., 2005; Aitken et al., 2003; Cigolini et } \\
\text { al., 2004; Vonderembse et al., } 2006\end{array}$ \\
\hline $\begin{array}{l}\text { Postponement } \\
\text { strategies }\end{array}$ & $\begin{array}{l}\text { Demand uncertainty, } \\
\text { product variety, } \\
\text { customer lead time, } \\
\text { customer service, } \\
\text { volume of production }\end{array}$ & $\begin{array}{l}\text { Design-to-order (DTO), make-to- } \\
\text { order (MTO), assemble-to-order } \\
\text { (ATO), make-to-stock (MTS), } \\
\text { Inventory centralisation / } \\
\text { decentralisation }\end{array}$ & $\begin{array}{l}\text { Feitzinger \& Lee, 1997; Naylor et al., 1999; Pagh \& } \\
\text { Cooper, 1998; Olhager, 2003; Yang et al., } 2004\end{array}$ \\
\hline
\end{tabular}




\subsection{Simulation Models}

The reviewed literature included some articles on simulation modelling which was carried out as a test bed for demand oriented strategies. $\mathrm{Li}$ and O'Brien (2001) developed a simulation model linking postponement strategies and demand uncertainty to performance. Some results supported Fisher's (1997) model, other results were not supportive. Payne and Peters (2004) reported on a simulation model created for a particular case company to assess the performance benefits of segmenting production based on product criteria: total demand per week, predictability of demand, order value, frequency of order, average order weight, substitutability of product, and number of customers per year. Products were split into 3 clusters based on a rule base: dispersed stock, centralised stock, and finish to order. Simulation showed performance improvement, particularly in inventory holding. Similarly Harris et al. (2010) carried out a simulation experiment to test
Fisher's (1997) theory. Physically efficient supply chains had lower costs, and market responsive supply chains had greater availabilities, "matching" supply chains had better profits, thus confirming Fisher's theory. Wong and Hvolby (2007) used simulation analysis to evaluate a supply chain alignment where a toy manufacturer with highly volatile demand tried order point penetration relocation, lead time reduction, and coordination with customers. Inventory reductions were achieved.

The results from the simulation research are supportive of strategic alignment to product / market contingencies. Performance improvements have been demonstrated.

\subsection{Empirical Research}

The fifth theme in the literature is the theme of empirical research. The following table lists the research within this theme as identified through the literature review.

Table 6 Empirical Research on Demand-oriented Strategy

\begin{tabular}{|c|c|c|}
\hline Reference & Investigation & Findings \\
\hline Lamming et al., 2000 & $\begin{array}{l}\text { Sixteen cases were classified on the } \\
\text { basis of functional or innovative } \\
\text { products. }\end{array}$ & Needed a third determinant - complexity. \\
\hline $\begin{array}{l}\text { Randall \& Ulrich, } \\
2001\end{array}$ & $\begin{array}{l}\text { Survey linking product variety, SC } \\
\text { strategy, and performance. }\end{array}$ & $\begin{array}{l}\text { Strategy depends on whether product variety results in } \\
\text { higher production costs or higher market mediation costs. }\end{array}$ \\
\hline Godsell et al., 2011 & $\begin{array}{l}\text { A case testing the DWV3 } \\
\text { methodology of market segmentation. }\end{array}$ & $\begin{array}{l}\text { Volume and variety were the discriminating contingencies. } \\
\text { Concept of market qualifiers / order winners was not very } \\
\text { useful. }\end{array}$ \\
\hline Randall et al., 2003 & Survey testing Fisher's (1997) model. & $\begin{array}{l}\text { Overall confirmation of Fisher's (1997) model linking } \\
\text { contingencies to SC configurations, but did not test for } \\
\text { performance. }\end{array}$ \\
\hline Lovell et al., 2005 & $\begin{array}{l}\text { Application of product-specific supply } \\
\text { chain configurations. }\end{array}$ & $\begin{array}{l}\text { Configurations were differentiated on inventory } \\
\text { centralisation / decentralisation. }\end{array}$ \\
\hline $\begin{array}{l}\text { Wong, Stentoft } \\
\text { Arlbjørn, Hvolby, \& } \\
\text { Johansen, } 2006 \\
\end{array}$ & Application of Fisher's (1997) model. & $\begin{array}{l}\text { Found it necessary to add one more "intermediate" type of } \\
\text { product to Fisher's functional / innovative types. }\end{array}$ \\
\hline $\begin{array}{l}\text { Selldin \& Olhager, } \\
2007 \text { Wagner et al., } \\
2012 \text { Qi et al., } 2009\end{array}$ & Survey, testing Fisher's model. & Found limited support for Fisher's model. \\
\hline Lo \& Power, 2010 & Survey, testing Fisher's model. & Fisher's model was not supported. \\
\hline Caniato et al., 2009 & $\begin{array}{l}\text { Applied } 9 \text { strategic alignment models } \\
\text { to } 13 \text { cases. }\end{array}$ & Alignment models did not hold up. \\
\hline Sun et al., 2009 & $\begin{array}{l}\text { Tested Lee's (2002) framework using } \\
\text { a survey. }\end{array}$ & $\begin{array}{l}\text { Lee's framework was supported. Performance } \\
\text { improvements found with alignment. }\end{array}$ \\
\hline $\begin{array}{l}\text { Liu, Shah, \& } \\
\text { Babakus, } 2012\end{array}$ & $\begin{array}{l}\text { Tested own model of mass } \\
\text { customisation. }\end{array}$ & $\begin{array}{l}\text { Mass customisation was found beneficial for demand } \\
\text { uncertainty. }\end{array}$ \\
\hline
\end{tabular}

Fisher's (1997) model has been the focus of most of the empirical research. Generally empirical research has found support for Fisher's hypothesis. However, most of the research measured the strategy by the strategic goals rather than the actual configurations that were implemented and most empirical research also did not test for performance improvement of companies who had matched their strategies to product demand. Lamming et al. (2000) tested Fisher's classification of supply chains on the basis of innovative and functional products in the context of supply networks. They investigated 16 cases, where they found general support for Fisher's framework, however they found it necessary to include one more dimension - complexity - in the classification. Complex products led to complex supply networks, with attendant issues of IT complexity. A few survey studies (Randall et al., 2003; Qi et al., 2009) have found that Fisher's strategic prescriptions were followed. However, crucially, these studies did not test if Fisher's prescriptions led to performance improvements. Wong et al., (2006) validated Fisher's model, but found it necessary to add a third "intermediate" type 
of product in-between Fisher's functional and innovative products. Two surveys (Selldin \& Olhager, 2007; Wagner et al., 2012) have found that the adoption of Fisher's suggested strategies was not significant, but there was performance improvement for companies following the recommended strategies. The survey carried out by Sun et al. (2009) validated Lee's (2002) model, which is an extension of Fisher's model. In a dissenting study, Lo and Power (2010) tested Fisher's model through a survey. They did not find support for an association between product nature and strategy, and that efficiency was paramount for firms and most firms pursued both efficiency and responsiveness goals. Thus Fisher's hypothesis did not hold up.

In summary, empirical research has provided mixed results for the theories in this area. Research is in disagreement with theory in regard to discriminant contingencies for strategy determination (Caniato et al., 2009; Godsell et al., 2011; Lamming et al., 2000; Randall \& Ulrich, 2001). Supply chains are not aligning their strategy to product demand, and evidence for performance improvement of conforming companies is scant. Research is also scant on the actual configurations adopted for strategy alignment. Contrary to common scholarly prescriptions, empirical research shows that companies found the goal of efficiency more compelling than other goals such as responsiveness (Godsell et al., 2011; Lo \& Power, 2010).

\section{SYNTHESIS OF THE REVIEWED LITERATURE}

\subsection{Contingency classification}

There are numerous contingencies identified in the reviewed literature. Not all of these contingencies are independent. For example, the phase of product life cycle is related to demand uncertainty. It is desirable to condense the various contingencies in the literature into a parsimonious set that captures the essential diversity. Our review indicates that the contingencies could be classified into the following:

Demand variability / uncertainty: There is consensus in this research that demand variability is the primary variable for strategy determination. Variability of product demand is exacerbated by low production volumes, product variety, short product life, and product complexity. Further, the rate of market growth is dictated by the stage of product life cycle and fast growth and decline of market are problematic on account of demand variability. The goals of small customer lead time and high customer service (fill rate) is difficult to meet when demand uncertainty is high. Thus all these variables can be folded into the dimension of demand uncertainty.

Product variety: When the product variety is high, the cost of obsolescence or markdowns can be high. Low production volumes and short product life exacerbate this problem. Thus these contingencies constitute a second dimension.

Supply uncertainty is an independent contingency of its own. With the globalisation of many supply chains, the risk of supply disruption has increased. Timely delivery of materials, yield and quality of materials have become more of a concern. Authors have expressed concern mainly for emerging supply chains.

Desired customer lead time is the fourth determinant in the selection of supply chain configurations. Where customers are not prepared to wait for their orders, supply chains need to be designed to fulfil customer orders within the desired customer lead time.

Proposition 1: The four variables of product variety, demand uncertainty, supply uncertainty, and customer lead time represent the "essential" contingencies in the determination of supply chain configurations.

\subsection{Contingency-configuration Framework}

The default goal of firms is efficiency - to deliver products at the lowest cost possible. The literature appears to agree that all of the following configurations will generally support the goal of efficiency: waste elimination, information sharing, supply chain integration, continuous replenishment, level scheduling, and kanban control.

Proposition 2: There are generic configurations, such as waste elimination and supply chain collaboration, which improve supply chain performance and are applicable irrespective of supply chain contingencies.

However, the demands of customer service may require firms to sacrifice some efficiency. Firms respond to these product / market contingencies by configuring their supply chains. A framework of supply chain configurations, synthesised from the literature is presented in the Table 7.

Contingencies are the independent variables, shown at the top. The four "essential" contingencies, distilled from the literature are: product variety, demand uncertainty/variability, desired customer lead time, and supply uncertainty or risk. Configurations are the dependent variables, listed on the left column. Relationships between the two sets of variables may be positive or negative. The framework, as shown above sums up the reviewed literature.

\section{DISCUSSION AND FUTURE RESEARCH DIRECTIONS}

In this section, we aim at positioning our research against previous contributions. As no such attempt of a literature review has been made, we summarize and systemize related literature. This is justified as the underlying issues are frequently discussed in supply chain management related 
research. We structure the subsequent discussion accordingly following up on the previously presented findings and positioning our own research.

Table 7 Framework of Supply Chain Configurations Found in the Reviewed Literature

\begin{tabular}{|c|c|c|c|c|}
\hline \multirow[b]{2}{*}{ Configurations } & \multicolumn{4}{|c|}{ Contingencies } \\
\hline & $\begin{array}{l}\text { Product } \\
\text { variety }\end{array}$ & $\begin{array}{l}\text { Demand } \\
\text { uncerta- } \\
\text { inty }\end{array}$ & $\begin{array}{l}\text { Custom- } \\
\text { er lead } \\
\text { time }\end{array}$ & $\begin{array}{l}\text { Supply } \\
\text { uncerta- } \\
\text { inty }\end{array}$ \\
\hline $\begin{array}{l}\text { Positioning of } \\
\text { decoupling point } \\
\text { and } \\
\text { postponement }\end{array}$ & + & + & - & \\
\hline $\begin{array}{l}\text { Manufacturing } \\
\text { capacity buffer }\end{array}$ & & + & + & \\
\hline $\begin{array}{l}\text { Lead time } \\
\text { reduction }\end{array}$ & & + & + & \\
\hline Modularisation & + & & & \\
\hline $\begin{array}{l}\text { Inventory buffer } \\
\text { stock }\end{array}$ & & + & + & + \\
\hline Supplier selection & & & & + \\
\hline $\begin{array}{l}\text { Rapid } \\
\text { reconfiguration }\end{array}$ & + & + & & \\
\hline $\begin{array}{l}\text { Improved } \\
\text { forecasting }\end{array}$ & + & + & & \\
\hline $\begin{array}{l}\text { Inventory } \\
\text { centralisation }\end{array}$ & + & + & - & \\
\hline Top up pipeline & & & & + \\
\hline $\begin{array}{l}\text { Alternative } \\
\text { suppliers }\end{array}$ & & & & + \\
\hline
\end{tabular}

(Legend: '+' indicates a positive relationship, '-' indicates a negative relationship)

\subsection{Contingencies}

Numerous contingency variables have been suggested in the literature. This raises the question of whether these variables are independent and whether all these variables are necessary. For example, stage of life cycle is of interest because it affects demand variability and production volumes. When these two later variables are included, the stage of life cycle appears redundant as a contingency variable. Godsell et al. (2011) attempted to implement the DWV3 contingencies to a particular company and found that only two variables, production volumes and demand variability, sufficed. Similarly Canioto et al. (2009) attempted to implement nine strategy models to 13 case companies, and found that most of the contingency variables were not applicable. Thus research to find a parsimonious set of contingencies appears desirable.
$\boldsymbol{R Q}$ 1: What is the most salient and parsimonious set of contingency variables in the determination of supply chain configurations?

\subsection{Relationship Between Contingencies and Configurations}

Supply chain literature is generally agreed on the relationship between contingencies and configurations presented earlier in section 6.2. However, there is by no means a complete agreement on the relationships. For instance, rapid reconfiguration permits quick change of products, and thus appears desirable for small production volumes but it also makes it feasible to reduce batch sizes, reduce inventory holdings and improve cost-efficiency. In this way rapid reconfiguration appears to contribute to the goals of both responsiveness and efficiency. Similar comments can be made for information sharing or improved forecasting. Thus there is a need to study each supply chain configuration on its own merit, its suitability for different contingencies, its compatibility with other configurations, and its effect on various strategic goals.

In this context, the role played by supply chain integration and information sharing is of particular interest. Fisher (1997) contented that information sharing and continuous replenishment were suitable for stable demand. Adamides et al. (2008) suggested the employment of collaboration for lean supply networks. The authors in the lean-agile school have emphasised that virtual network, supply chain integration, and information sharing as essential response to demand variability. Handfield \& Bechtel (2002) also suggested that collaboration is required for supply chain agility. This raises the question does supply chain integration reduce costs, or increase customer service, or both? Current research has taken a macro approach - a set of contingencies is matched to a set of configurations, labelled strategies. What we are arguing for is a micro approach - research needs to be carried out on individual relationships between contingencies and configurations.

$\boldsymbol{R Q}$ 2: How are contingency variables related to configuration variables? Is the framework presented in Table 7 valid?

\subsection{Definition of Strategy Labels}

"Lean is efficient".

"Agility subsumes lean"

"Agility is responsive"

"Agility subsumes flexibility".

The above debate persists in the research literature, without a clear resolution. In this article we would like to argue that authors have attached the strategy labels to strategic goals, but have not clearly delineated the constituting configurations in these strategies. Fisher (1997) identified efficient and responsive strategies. The lean-agile school identified lean and agile strategies (Waddington et al., 2002). It appears that efficient and lean strategies are similar, 
while responsive strategy corresponds to agile strategy. Cigolini et al. (2004) however found it necessary to introduce lean strategy as an intermediate strategy between Fisher's efficient and responsive strategies. Further progress in research in this field requires a consensus on the definition of the strategies.

$\boldsymbol{R} \boldsymbol{Q}$ 3: How can configuration clusters, or strategies, be clearly delineated?

\subsection{Trade-offs}

Businesses exist to increase the wealth of the shareholders, so cost-efficiency is the default goal of supply chain design. This is self-evident and is also established by empirical research (Lo \& Power, 2010). Given stable demand, companies are able to pursue the goal of efficiency vigorously. As the pressure of the contingencies placed on a supply chain increases, some of this efficiency is necessarily sacrificed. Thus supply chain design is a multi-criteria decision making problem (MCDM), where costefficiency is sacrificed to satisfy customer service requirements. Empirical research provides some support for this viewpoint. Feitzinger \& Lee (1997) said "Clashing priorities make it hard to create the most efficient supply network". van Hoek (2000) supported the idea of trade-offs stating that leagility is a particular compromise between lean and agility that may suit some contingencies, but in other contingencies requiring a high level of agility, the emphasis on lean may need to be downplayed. Strategies are often shown as discrete choices in $2 \times 2$ matrices.

Lean vs. agile or efficient vs. responsive are portrayed as discrete choices, but of course these are strategies in a continuum. In the same vein, Borgström \& Hertz (2011) criticised Fisher's model for dichotomising the functional / innovative product spectrum, and for dichotomising efficient / responsive strategies. Godsell et al. (2011) found that their case company's objective was "availability of the right product, at the right time at the lowest possible cost". This clearly demonstrates the multi-criteria decision making (MCDM) nature of supply chain configuration selection. Following the MCDM parlance, a sole pursuit of efficiency would be a "pure" strategy, yielding the lowest costs possible. Any deviation from this strategy towards other goals would be a "mixed" strategy, and would increase the costs. Thus optimal solutions exist on a Paretooptimal front. This is the concept of the trade-off of strategic goals, which has been discussed in the manufacturing strategy literature for a long time (Schmenner \& Swink, 1998).

Selldin and Olhager (2007) found support for the existence of a "supply chain frontier" that indicated trade-offs between responsiveness and efficiency. Such a frontier is proposed below in Figure 8 . Efficiency appears on the $\mathrm{x}$-axis, and other goals, such as customer service or response time appear on the $y$ - axis. The Pareto-optimal solutions appear on the frontier.

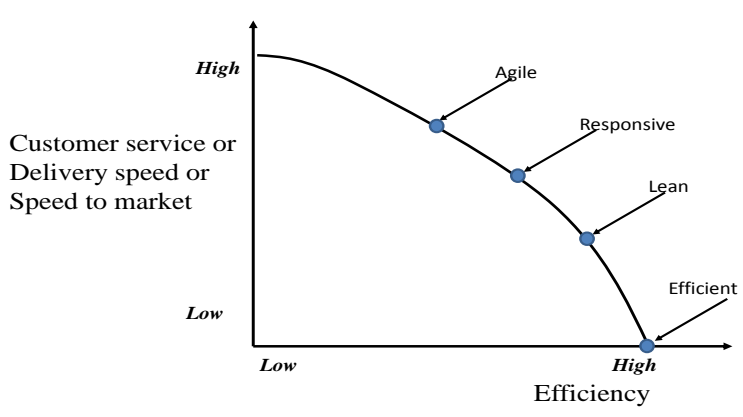

Figure 8 Supply Chain Frontier

We have labelled the frontier at various points tentatively indicating currently popular strategies in the literature. Current literature asserts that "lean is cost-oriented" or "the goal of responsiveness is product availability", or "agility is flexible", without exploring the trade-offs involved or the set of configurations behind each strategy clusters. Theoretical as well as empirical research is needed to map out the frontier.

For example, in regard to mapping "lean" strategy in the frontier, the literature often uses the words "lean" and "efficient" interchangeably. In the terminology of MCDM, efficient strategy represents a pure strategy - a pursuit of cost reduction at the possible expense of other strategic goals. Lean strategy is however a particular choice between efficiency and agility, possibly a Pareto-optimal strategy. Thus we would suggest that lean strategy is not a purely efficient strategy. For example, lean strategy emphasizes quick set-ups, which is a pursuit of agility. There is evidence that lean strategy achieves both efficiency and flexibility (Adler, Goldoftas, \& Levine, 1999). Thus the synonymous use of "lean" and "efficient" is problematic.

We are arguing here for exploring the supply chain frontier, clear delineation of where on the frontier various strategies lie, and what are the tradeoffs involved.

$\boldsymbol{R Q}$ 4: What are the trade-offs involved in the supply chain strategies proposed in the literature?

\subsection{Manufacturing Strategy versus Supply Chain Strategy}

The discourse on supply chain strategy is a continuation of the discourse on manufacturing strategy, which was prevalent in earlier years. After the onset of the supply chain concept, which views the product provision network (a.k.a. supply chain) from a holistic perspective, the research on supply chain strategy has gained momentum. However, our review shows that much of the discussion is still centred on the focal firm, not so much on the supply chain (see also (Seuring, 2009)). Supply chain issues, such as 
supplier integration, collaborative forecasting, information sharing, supplier involvement, supplier development, supplier selection etc. do not feature prominently in the discussion of supply chain strategies. Thus a research question can be proposed, which essentially is an extension of research question 2 , posed earlier.

$\boldsymbol{R Q}$ 5: What are the relationships between product demand contingencies and specifically supply chain configurations, such as supplier collaboration or information sharing? Are these configurations generally beneficial or apply to specific contingencies?

\subsection{Dynamics of Supply Chain Strategy}

Supply chain strategy is a firm's response to the exigencies of the commercial environment. Since the environment is dynamic, it is to be expected that supply chain strategies would be dynamic as well. However, research on dynamic strategies is limited. Christopher \& Towill (2000) presented a migratory model describing how the market for personal computers had changed over time and how the strategies evolved in response to the new challenges. Aitken, Childerhouse, \& Towill (2003) provided evidence of how supply chain strategy changed in a case company as the product traversed its life cycle. Borgström \& Hertz (2011) have criticised Fisher's model, saying that it does not allow for dynamic circumstances, such as change of ownership, change of suppliers, change in market situations, etc. that would cause changes in SC strategy - what Fisher (1997) calls a misfit may simply be a result of dynamic changes. The most promising resent development on the theoretical side is the rise of the dynamic capability approach in strategic management (Eisenhardt and Martin, 2000), which has been taken up in related research on supply chain management (Defee and Fugate, 2010; Beske, 2012; Beske et al., 2014), while the link into supply chain strategies and configurations is not really explored yet. These few papers found in the literature show that there is considerable untapped scope for research in this area.

$\boldsymbol{R Q}$ 6: How do supply chain strategies evolve in response to dynamic changes?

\subsection{Alignment and Performance}

The implied or explicit goal of the reviewed research is performance improvement, via the alignment of product demand with supply chain design. As discussed in an earlier section, there is some empirical research on the extent of alignment, but there is not much empirical research on the relationship between alignment and performance, except (Selldin \& Olhager, 2007; Wagner et al., 2012). Thus this issue is ripe for future empirical investigation.

$\boldsymbol{R Q}$ 7: How does the match between contingencies and configurations affect the performance of supply chains?

\section{LIMITATIONS AND CONCLUSION}

In conclusion, the reviewed literature generally supports Fisher's model of classifying products into functional and innovative and matching them to efficient and responsive strategies. Even though the authors in the lean-agile school have rephrased the strategies as lean and agile, the basic argument (and the presented evidence) lends support to Fisher's model.

In many respects current research in demandoriented supply chain strategies reflects its origin in manufacturing strategy. Following Skinner (1969 and 1974), discussions are anchored on cost vs. other objectives. Authors are still emulating Hayes and Wheelwright (1979) in mapping volume and variety into agile and efficient supply chains. Our review of the literature found that supply chain strategy needs more focus on the network aspect of strategy than the current focus on manufacturing aspects, which reflect the origin of this discourse. Research has also focused on strategy goals, such as agility, flexibility, responsiveness, and cost-efficiency rather than the supply chain design configurations and the trade-offs inherent in these configurations. These aspects of supply chain strategies warrant more study. It is also timely to identify the salient dimensions of contingency of product demand / market and map out the various configurations or management initiatives in the contingency space.

The contribution of this article is a review and synthesis of the extant literature leading to a framework of contingencies and configurations as found in the literature. Stemming from this review, some pointers for future research are offered. The limitation of this article is that while efforts have been made to reduce bias by conducting the literature review in a systematic manner, this work builds on the seminal paper of Fisher (1997) and represents the authors' interpretation of the literature.

\section{ACKNOWLEDGEMENT}

Anonymous referee for suggestions that improved the paper.

\section{REFERENCES}

Adamides, E. D., Karacapilidis, N., Pylarinou, H., \& Koumanakos, D. (2008). Supporting collaboration in the development and management of lean supply networks. Production Planning \& Control, 19(1), pp.35.

Adler, P. S., Goldoftas, B., \& Levine, D. I. (1999). Flexibility versus efficiency? A case study of model changeovers in the Toyota production system. Organization Science, 10(1), pp.43-68.

Aitken, J., Childerhouse, P., Christopher, M., \& Towill, D. (2005). Designing and managing multiple pipelines. Journal of Business Logistics, 26(2), pp.73-96. 
Aitken, J., Childerhouse, P., \& Towill, D. (2003). The impact of product life cycle on supply chain strategy. International Journal of Production Economics, 85(2), pp.127-140.

Aitken, J., Christopher, M., \& Towill, D. (2002). Understanding, implementing and exploiting agility and leanness. International Journal of Logistics, 5(1), pp.59-74.

Beske, P. (2012). Dynamic capabilities and sustainable supply chain management. International Journal of Physical Distribution \& Logistics Management, 42(4), pp.372-387.

Beske, P., Land, A., \& Seuring, S. (2014). Sustainable supply chain management practices and dynamic capabilities in the food industry: A critical analysis of the literature. International Journal of Production Economics, 152, pp.131-143.

Borgström, B., \& Hertz, S. (2011). Supply Chain Strategies: Changes in Customer Order-Based Production. Journal of Business Logistics, 32(4), pp.361-373.

Caniato, F., Caridi, M., Castelli, C. M., \& Golini, R. (2009). A contingency approach for SC strategy in the Italian luxury industry: Do consolidated models fit? International Journal of Production Economics, 120(1), pp.176-189. doi:http://dx.doi.org/10.1016/j.ijpe.2008.07.027

Childerhouse, P., Aitken, J., \& Towill, D. R. (2002). Analysis and design of focused demand chains. Journal of Operations Management, 20(6), 675-689.

Christopher, M. (2000). The Agile Supply Chain: Competing in Volatile Markets. Industrial Marketing Management, 29(1), pp.37-44.

Christopher, M., \& Gattorna, J. (2005). Supply chain cost management and value-based pricing. Industrial Marketing Management, 34(2), pp.115-121.

Christopher, M., \& Towill, D. (2001). An integrated model for the design of agile supply chains. International Journal of Physical Distribution \& Logistics Management, 31(4), pp.235-246.

Christopher, M., \& Towill, D. R. (2000). Supply chain migration from lean and functional to agile and customised. Supply Chain Management: An International Journal, 5(4), pp.206-213. doi:10.1108/13598540010347334

Christopher, M., \& Towill, D. R. (2002). Developing market specific supply chain strategies. International Journal of Logistics Management, 13(1), pp.1-14.

Cigolini, R., Cozzi, M., \& Perona, M. (2004). A new framework for supply chain management: conceptual model and empirical test. International Journal of Operations \& Production Management, 24(1), 7-41.

Collin, J., Eloranta, E., \& Holmström, J. (2009). How to design the right supply chains for your customers. Supply Chain Management: An International Journal, 14(6), pp.411-417.

Clifford Defee, C., \& Fugate, B. S. (2010). Changing perspective of capabilities in the dynamic supply chain era. The International Journal of Logistics Management, 21(2), pp.180-206.

Eisenhardt, K. M., \& Martin, J. A. (2000). Dynamic capabilities: what are they? Strategic Management Journal, 21(10-11), pp.1105-1121.

Feitzinger, E., \& Lee, H. L. (1997). Mass customization at Hewlett-Packard: the power of postponement. Harvard Business Review, 75, 116-123.

Fisher, M., Hammond, J., Obermeyer, W., \& Raman, A. (1997). Configuring a supply chain to reduce the cost of demand uncertainty. Production and Operations Management, 6(3), pp.211-225.

Fisher, M. L. (1997). What Is the Right Supply Chain for Your Product? Harvard Business Review, 75(2), pp.105-116.

Godsell, J., Diefenbach, T., Clemmow, C., Towill, D., \& Martin, C. (2011). Enabling supply chain segmentation through demand profiling. International Journal of Physical Distribution \& Logistics Management, 41(3), pp.296-314.

Handfield, R. B., \& Bechtel, C. (2002). The role of trust and relationship structure in improving supply chain responsiveness. Industrial Marketing Management, 31(4), pp.367-382.

Harris, G. A., Componation, P. J., \& Farrington, P. A. (2010). An Exploration of Fisher's Framework for the Alignment of Supply Chain Strategy With Product Characteristics. Engineering Management Journal, 22(4), pp.31-42.

Kassarjian, H. H. (1977). Content analysis in consumer research. Journal of Consumer Research, pp.8-18.

Lamming, R., Johnsen, T., Zheng, J., \& Harland, C. (2000). An initial classification of supply networks. International Journal of Operations \& Production Management, 20(6), pp.675-691.

Lee, H. L. (2002). Aligning Supply Chain Strategies with Product Uncertainties. California Management Review, 44(3), pp.105-119.

Li, D., \& O'Brien, C. (2001). A quantitative analysis of relationships between product types and supply chain strategies. International Journal of Production Economics, 73(1), pp.29-39.

Liu, G. J., Shah, R., \& Babakus, E. (2012). When to Mass Customize: The Impact of Environmental Uncertainty. Decision Sciences, 43(5), pp.851-887.

Lo, S. M., \& Power, D. (2010). An empirical investigation of the relationship between product nature and supply chain strategy. Supply Chain Management, 15(2), pp.139-153.

Lovell, A., Saw, R., \& Stimson, J. (2005). Product valuedensity: managing diversity through supply chain segmentation. International Journal of Logistics Management, The, 16(1), pp.142-158.

Mason-Jones, R., Naylor, B., \& Towill, D. R. (2000a). Engineering the leagile supply chain. International Journal of Agile Management Systems, 2(1), pp.54-61. doi:10.1108/14654650010312606

Mason-Jones, R., Naylor, B., \& Towill, D. R. (2000b). Lean, agile or leagile? Matching your supply chain to the marketplace. International Journal of Production Research, 38(17), 4061-4070.

Naylor, J. B., Naim, M. M., \& Berry, D. (1999). Leagility: Integrating the lean and agile manufacturing paradigms in the total supply chain. International Journal of Production Economics, 62(1,2), pp.107118.

Olhager, J. (2003). Strategic positioning of the order penetration point. International Journal of Production Economics, 85(3), pp.319-329.

Pagh, J. D., \& Cooper, M. C. (1998). Supply chain postponement and speculation strategies: how to choose the right strategy. Journal of Business Logistics, 19, pp.13-34.

Payne, T., \& Peters, M. J. (2004). What is the right supply chain for your products? The International Journal of Logistics Management, 15(2), pp.77-92. 
Qi, Y., Boyer, K. K., \& Zhao, X. (2009). Supply Chain Strategy, Product Characteristics, and Performance Impact: Evidence from Chinese Manufacturers. Decision Sciences, 40(4), pp.667-695.

Randall, T., \& Ulrich, K. (2001). Product variety, supply chain structure, and firm performance: Analysis of the US bicycle industry. Management Science, 47(12), pp.1588-1604.

Randall, T. R., Morgan, R. M., \& Morton, A. R. (2003). Efficient versus Responsive Supply Chain Choice: An Empirical Examination of Influential Factors. Journal of Product Innovation Management, 20(6), pp.430443.

Schmenner, R. W., \& Swink, M. L. (1998). On theory in operations management. Journal of Operations Management, $\quad 17(1), \quad$ pp.97-113. doi:http://dx.doi.org/10.1016/S0272-6963(98)00028$\mathrm{X}$

Selldin, E., \& Olhager, J. (2007). Linking products with supply chains: testing Fisher's model. Supply Chain Management: An International Journal, 12(1), pp.4251.

Seuring, S. (2009). The product-relationship-matrix as framework for strategic supply chain design based on operations theory. International Journal of Production Economics, 120(1), pp.221-232.

Seuring, S., \& Gold, S. (2012). Conducting content-analysis based literature reviews in supply chain management. Supply Chain Management: An International Journal, 17(5), pp.544-555.

Shah, R., \& Ward, P. T. (2007). Defining and developing measures of lean production. Journal of Operations Management, 25(4), pp.785-805.

Skinner, W. (1969). Manufacturing--missing link in corporate strategy. Harvard Business Review, 47(3), pp.136-145.

Skinner, W. (1974). The focused factory. Harvard Business Review, 52(3), pp.113-121.

Stratton, R., \& Warburton, R. (2003). The strategic integration of agile and lean supply. International Journal of Production Economics, 85(2), pp.183-198.

Sun, S.-Y., Hsu, M.-H., \& Hwang, W.-J. (2009). The impact of alignment between supply chain strategy and environmental uncertainty on SCM performance. Supply Chain Management, 14(3), pp.201-212.

Towill, D., \& Christopher, M. (2002). The supply chain strategy conundrum: to be lean or agile or to be lean and agile? International Journal of Logistics, 5(3), pp.299-309.

Towill, D. R., \& Christopher, M. (2007). Do not lean too far-evidence from the first decade. International Journal of Agile Systems and Management, 2(4), pp.406-424.

van der Vorst, J. G. A. J., van Dijk, S. J., \& Beulens, A. J. M. (2001). Supply chain design in the food industry. The International Journal of Logistics Management, 12(2), pp.73-86.

van Hoek, R. I. (2000). The thesis of leagility revisited. International Journal of Agile Management Systems, 2(3), pp.196-201

Vonderembse, M. A., Uppal, M., Huang, S. H., \& Dismukes, J. P. (2006). Designing supply chains: Towards theory development. International Journal of Production Economics, 100(2), pp.223-238.

Waddington, T., Childerhouse, P., \& Towill, D. R. (2002). Engineer your supply chain to cope with demand uncertainties. IOM Control Magazine, 27(10), pp.1418.

Wagner, S. M., Grosse-Ruyken, P. T., \& Erhun, F. (2012). The link between supply chain fit and financial performance of the firm. Journal of Operations Management, 30(4), pp.340-353.

Wong, C. Y., \& Hvolby, H. H. (2007). Coordinated responsiveness for volatile toy supply chains. Production Planning \& Control, 18(5), pp.407-419.

Wong, C. Y., Stentoft Arlbjørn, J., Hvolby, H.-H., \& Johansen, J. (2006). Assessing responsiveness of a volatile and seasonal supply chain: a case study. International Journal of Production Economics, 104(2), pp.709-721.

Yang, B., Burns, N. D., \& Backhouse, C. J. (2004). Management of uncertainty through postponement. International Journal of Production Research, 42(6), pp.1049-1064.

Chuda Basnet is an Associate Professor at the Waikato Management School, New Zealand. His research interests are in the areas of manufacturing modelling, supply chain management and decision support systems.

Stefan Seuring is a full professor of supply chain management at the University of Kassel, Germany. Previously, he worked at the University of Waikato, Waikato Management School, New Zealand. Stefan has published various papers on sustainable supply chain management, but also on supply chain strategy and the application of management accounting tools across supply chains. 